\title{
PERBANDINGAN PEMAHAMAN KONSEP SISWA DENGAN MENGGUNAKAN MODEL PEMBELAJARAN CONTEXTUAL TEACHINGANDLEARNING DAN PENEMUAN TERBIMBING DI KELAS VII MTS.S AL-JIHAD MEDAN
}

\author{
Oleh: \\ Raja Sopiyah Nasution ${ }^{1}$, Syafari $^{2}$ \\ ${ }^{1,2)}$ Program Studi Pendidikan Matematika, FMIPA, Universitas Negeri Medan, \\ Jl. Willem Iskandar Psr. V Medan Estate, Medan, Indonesia, 20221 \\ e-mail : raja.sofiah.nasution@gmail.com
}

\begin{abstract}
Abstrak
Penelitian ini bertujuan untuk mengetahui apakah terdapat perbedaan kemampuan pemahaman konsep siswa yang diajarkan dengan menggunakan model pembelajaran Contextual Teaching And Learning (CTL) dan siswa yang diajarkan dengan model pembelajaran Penemuan Terbimbing di MTs.S Al-Jihad Medan. Penelitian ini dirancang dan dilaksanakan dengan menggunakan metode eksperimen semu dan melibatkan sampel sebanyak 60 siswa. Penelitian ini menggunakan instrumen berbentuk uraian yaitu pretest dan postest yang digunakan untuk mengetahui kemampuan pemahaman konsep matematika siswa. Dari hasil penelitian diperoleh nilai rata-rata postest 81,33 untuk kelas eksperimen A dan 78,4 untuk kelas eksperimen B. Data yang diperoleh dianalisis dengan menggunakan uji Chi-Square, uji F, dan uji t. Berdasarkan pengujian tersebut disimpulkan bahwa terdapat perbedaan kemampuan pemahaman konsep siswa yang diajarkan dengan menggunakan model pembelajaran Contextual Teaching And Learning (CTL) dan siswa yang diajarkan dengan model pembelajaran Penemuan Terbimbing di MTs.S Al-Jihad MedanT.A 2017/2018.
\end{abstract}

Kata Kunci : Eksperimen Semu, Pemahaman Konsep, CTL, Penemuan Terbimbing

\begin{abstract}
This study aims to determine whether there is a difference in the ability to understand students' concepts taught by using Contextual Teaching And Learning (CTL) learning model and students taught with guided invention learning model at MTs.S Al-Jihad Medan. This study was designed and implemented using a quasi-experimental method and involved a sample of 60 students. This study uses the instrument in the form of a description of pretest and posttest used to determine the ability of understanding the concept of mathematics students. From the research result, it can be found the postest average value 81,33 for experiment class $A$ and 78,4 for experiment class $B$. The data obtained are analyzed by using Chi-Square test, F test, and t test. Based on the test, it can be concluded that there is a difference of students' concept comprehension ability taught by using Contextual Teaching And Learning (CTL) learning model and students taught by Guided Discovery model at MTs.S Al-Jihad MedanT.A 2017/2018.
\end{abstract}

Keyword : Quasi Experimen, Concept Understanding Ability, using Contextual Teaching And Learning, Guided Discovery

Raja Sopiyah Nasution, Syafari. Perbandingan Pemahaman Konsep Siswa dengan Menggunakan Model Pembelajaran Contextual Teaching and Learning dan Penemuan Terbimbing di Kelas VIIMts.S Al-Jihad Medan. Jurnal Inspiratif, Vol. 4, No. 1 April 2018. 


\section{Pendahuluan}

Pendidikan merupakan salah satu perwujudan peradaban manusia yang dinamis dan sarat perkembangan. Perubahan dan perkembangan pendidikan memang seharusnya terjadi sejalan dengan perubahan budaya kehidupan. Perubahan yang artinya perbaikan pendidikan pada semua tingkat perlu terus dilakukan sebagai antisipasi kepentingan masa depan. Maju dan mundurnya sebuah negara tidak terlepas dari sejauh mana mutu pendidikan itu sendiri. Pendidikan yang mendukung kemajuan pembangunan bangsa di masa mendatang tentu merupakan pendidikan yang mampu mengembangkan potensi peserta didik, sehingga yang bersangkutan mampu menghadapi problema kehidupan yang dihadapinya.

Dalam situasi masyarakat yang selalu berubah saat ini, idealnya pendidikan itu tidak hanya berorientasi pada masa lalu dan masa kini, tetapi sudah seharusnya merupakan proses yang mengantisipasi dan membicarakan masa depan. Pendidikan hendaknya melihat jauh kedepan dan memikirkan apa yang akan dihadapi peserta didik di masa yang akan datang. Menurut Buchori dalam Trianto (2010 : 5), bahwa pendidikan yang baik adalah pendidikan yang tidak hanya mempersiapkan para siswanya untuk suatu profesi atau jabatan, tetapi untuk menyelesaikan masalah masalah yang dihadapinya dalam kehidupan sehari - hari.

Selain itu, seperti yang di ungkapkan Trianto (2010 : 1-2). pendidikan yang mampu mendukung pembangunan di masa mendatang adalah pendidikan yang mampu mengembangkan potensi peserta didik, sehingga yang bersangkutan mampu menghadapi dan memecahkan problema kehidupan yang dihadapinya. Pendidikan harus menyentuh potensi nurani maupun potensi kompetensi peserta didik. Konsep pendidikan tersebut semakin penting ketika seseorang harus memasuki kehidupan dimasyarakat dan dunia kerja, karena yang bersangkutan harus mampu menerapkan apa yang dipelajari di sekolah untuk menghadapi problema yang dihadapi dalam kehidupan sehari-hari saat ini maupun yang akan datang.

Di dalam dunia pendidikan, matematika memegang peranan yang sangat penting. Banyak yang telah disumbangkankan matematika untuk kemajuan peradaban manusia. Shaddiq (2009 : 2) menyatakan matematika adalah kunci ke arah peluang-peluang. Bagi seorang siswa keberhasilan mempelajarinya akan membuka pintu karir yang cemerlang. Bagi para warganegara, matematika akan menunjang pengambilan keputusan yang tepat. Bagi suatu negara, matematika akan menyiapkan warganya untuk bersaing dan berkompetisi di bidang ekonomi dan tekhnologi.

Mengingat besarnya peranan matematika, maka tak heran jika pelajaran matematika diberikan pada setiap jenjang mulai dari prasekolah (TK), SD, SMP, SMA, sampai pada perguruan tinggi. Bahkan matematika dijadikan salah satu tolak ukur kelulusan siswa melalui diujikannya matematika dalam ujian nasional.

Kelemahan matematika pada siswa Indonesia tersebut dikarenakan pelajaran matematika (ilmu pasti) bagi anak - anak pada umumnya pelajaran yang tidak disenangi, kalau bukan pelajaran yang dibenci. Sikap negatif seperti ini muncul karena adanya persepsi bahwa pelajaran matematika yang sulit. Anggapan tersebut tidak terlepas dari persepsi yang berkembang dimasyarakat tentang matematika yang dianggap sebagai ilmu yang kering, hanya bersifat teori, penuh rumus yang membingungkan. Hal ini akan berdampak buruk terhadap prestasi belajar matematika siswa. Hal senada juga diungkapkan oleh Soekisno (2009) bahwa banyak faktor yang menyebabkan matematika dianggap pelajaran sulit, diantaranya adalah karakteristik matematika yang bersifat abstrak, logis, sistematis, dan penuh dengan lambang - lambang dan rumus yang membingungkan. Selain itu, beberapa pelajar tidak menyukai 
matematika karena matematika penuh dengan hitungan.

Dalam pembelajaran matematika sebenarnya tidak dituntut agar siswa hanya bisa menghafal dan mengingat keseluruhan simbol atau formula matematik melainkan juga mampu memahami dan mengartikan, sebab simbol - simbol tersebut bersifat "artificial" yang memiliki arti setelah sebuah makna diberikan kepadanya.

Banyak hal yang menyebabkan siswa sulit mempelajari matematika. Salah satu penyebabnya adalah kurangnya pemahaman siswa terhadap konsep konsep matematika. Padahal, senada dengan hal tersebut, Lerner dalam Abdurrahman (2012 : 204) mengemukakan bahwa "kurikulum bidang studi matematika hendaknya mencakup tiga elemen, (1) konsep, (2) keterampilan, dan (3) pemecahan masalah". Abdurrahman (2012 : 205) juga mengatakan bahwa "konsep menunjuk pada pemahaman dasar dan kemudian siswa dapat mengembangkan suatu konsep ketika mereka mampu mengklasifikasikan atau mengelompokkan benda atau mengasosiasikan suatu nama dengan kelompok benda tersebut". Selanjutnya Suryanto (2014) mengatakan bahwa "salah satu penyebab kegagalan dalam pembelajaran matematika adalah siswa tidak memahami konsep - konsep matematika. Banyak faktor yang menjadi penyebab rendahnya atau kurangnya pemahaman peserta didik terhadap konsep matematika, salah satu diantara metode pembelajaran yang digunakan pengajar kurang sesuai. Kesalahan konsep suatu pengetahuan saat disampaikan guru kepada siswanya bisa berakibat kesalahan fatal yang berkesinambungan".

Salah satu bukti bahwa pemahaman konsep matematika siswa masih tergolong rendah dapat terlihat dari hasil observasi berupa nilai tes kemampuan pemahaman konsep matematika pada materi bilangan pecahan di MTs.S Al-Jihad Medan. KKM yang ditetapkan di MTs.S Al-Jihad Medan yaitu 70. Dari tes awal kemampuan pemahaman konsep matematika yang dilakukan pada 32 orang siswa kelas $\mathrm{VIII}^{2}$, diperoleh rata-rata nilai tes awal kelas $\mathrm{VIII}^{2}$ adalah 38,84 dengan persentase kelulusan $16 \%$ (5 orang) dan tidak lulus 84\% (27 orang). Berdasarkan hasil observasi tersebut, dapat diketahui bahwa kemampuan pemahaman konsep matematika siswa kelas VIII $^{2}$ MTs.S AlJihad Medan masih rendah.

Untuk mengatasi hal-hal tersebut, maka seorang guru harus mampu memilih dan menentukan model atau pendekatan pembelajaran yang sesuai dengan materi pelajaran dan kebutuhan belajar siswa. Dalam perkembangan dunia pendidikan terdapat beberapa model pembelajaran yang tepat untuk meningkatkan pemahaman konsep siswa, yaitu model pembelajaran kontekstual (Contextual Teaching and Learning) dan model pembelajaran Penemuan Terbimbing.

Pembelajaran kontekstual dapat dikatakan sebagai suatu pendekatan pembelajaran yang mengakui dan menunjukkan kondisi alamiah dari pengetahuan. Menurut Tambelu (2013 : 27). "it is important in contextual learning in which students really learn from the beginning of knowledge, experiencing, and the context of their daily lives are linked to the concepts of studied in class, and then it is possible to implement in their daily lives" (Penting dalam pembelajaran kontekstual di mana siswa benar-benar belajar dari awal pengetahuan, pengalaman, dan konteks kehidupan sehari-hari mereka terkait dengan konsep belajar di kelas, dan kemudian memungkinkan untuk diterapkan dalam kehidupan sehari-hari mereka). Jika siswa mempelajari materi pelajaran yang disajikan melalui konteks kehidupan mereka dan menemukan arti sendiri di dalam proses pembelajaran, maka materi pelajaran akan tambah berarti dan menyenangkan.

Selain pembelajaran kontekstual, terdapat juga model Penemuan Terbimbing. Penemuan Terbimbing adalah suatu model pembelajaran yang lebih menekankan pada aktivitas siswa, siswa mencari dan menemukan jawaban sendiri dibawah bimbingan guru sehingga diharapkan mampu meningkatkan pemahaman konsep siswa. 


\section{Metode Penelitian}

Jenis penelitian yang digunakan adalah penelitian eksperimen semu (quasi experiment). Penelitian ini dilaksanakan di MTs.S Al-Jihad Medan dan dilaksanakan pada semester ganjil T.A 2017/2018. Populasi dalam penelitian ini adalah seluruh siswa kelas VII MTs.S Al-Jihad Medan T.A 2017/2018 yang terdiri dari 2 kelas. Pengambilan sampel dalam penelitian ini dilakukan dengan menggunakan teknik cluster random sampling. Dari seluruh jumlah siswa kelas MTs.S Al-Jihad Medan tersebut di pilih 2 kelas yang menjadi sampel masing-masing berjumlah 30 orang. Sampel kelas VII-2 yaitu kelas yang diajarkan dengan menggunakan model pembelajaran kontekstual dan kelas VII-1 yaitu kelas yang diajarkan dengan menggunakan model pembelajaran Penemuan Terbimbing. Instrumen penelitian ini menggunakan tes kemampuan pemahaman konsep matematika sebanyak 6 soal berbentuk uraian dimana setiap soal mengandung setiap indikator pemahaman konsep matematika. Analisis data yang digunakan dalam penelitian ini yaitu uji Chi-Square, uji F, dan uji t.

\section{Hasil Penelitian dan Pembahasan Hasil Penelitian}

Sebelum dilakukannya penelitian, tes yang akan diberikan kepada sampel terlebih dahulu divalidkan kepada tiga validator yaitu kepada dua dosen matematika UNIMED yaitu Ibu Ade Andriani, M.Pd dan Bapak Muliawan Firdaus, M.Si dan guru bidang studi matematika di MTs.S Al-Jihad Medan yaitu Nurul Husna, S.Pd.

\section{Deskripsi Hasil Pretest Kelas Eksperimen A dan Kelas Eksperimen B}

Sebelum melakukan pembelajaran terlebih dahulu dilakukan pemberian pretest yang bertujuan untuk mengetahui kemampuan awal dari siswa dan menjadi dasar dalam pengelompokkan siswa pada saat pembelajaran. Dari hasil pemberian pretest diperoleh nilai rata-rata pretest pada kelas eksperimen A adalah 51,1 sedangkan nilai rata-rata pretest untuk kelas eksperimen B adalah 50,8. Secara ringkas hasil pretest kedua kelas eksperimen diperlihatkan pada Tabel 1 berikut.

Tabel 1 Data Pretest Kedua Kelas Eksperimen

\begin{tabular}{|c|c|c|c|}
\hline No & Statistik & $\begin{array}{c}\text { Kelas } \\
\text { Eksperimen A }\end{array}$ & $\begin{array}{c}\text { Kelas } \\
\text { Eksperimen B }\end{array}$ \\
\hline 1 & Jumlah Siswa & 30 & 30 \\
\hline 2 & Jumlah Nilai & 1532 & 1524 \\
\hline 3 & Rata-Rata & 51,1 & 50,8 \\
\hline 4 & Varians & 30,54 & 29,95 \\
\hline 5 & Maksimum & 60 & 60 \\
\hline 6 & Minimum & 44 & 44 \\
\hline
\end{tabular}

\section{Deskripsi Hasil Postest Kelas Eksperimen A dan Kelas Eksperimen B}

Kedua kelas eksperimen diberikan perlakuan dengan model pembelajaran kontekstual (CTL) dan Penemuan Terbimbing. Setelah kedua kelas diberi perlakuan yang berbeda diberikan postest untuk mengetahui kemampuan pemahaman konsep matematika siswa. Soal yang dipakai adalah soal berbentuk uraian yang berjumlah 3 soal. Sebelum soal tersebut diberikan, dilakukan validasi soal kepada 3 orang ahli dan semua soal valid sehingga soal layak dipakai.

Dari hasil postest diperoleh ratarata postest kelas eksperiemen A dengan model pembelajaran kontekstual adalah 81,33 dan rata-rata postest kelas eksperimen

Raja Sopiyah Nasution, Syafari. Perbandingan Pemahaman Konsep Siswa dengan Menggunakan Model Pembelajaran Contextual Teaching and Learning dan Penemuan Terbimbing di Kelas VIIMts.S Al-Jihad Medan. Jurnal Inspiratif, Vol. 4, No. 1 April 2018. 
B dengan model pembelajaran Quantum Teaching adalah 78,4. Secara ringkas hasil postest kedua kelas diperlihatkan pada Tabel 2 berikut.

\section{Tabel 2}

Data Postest Kedua Kelas Eksperimen

\begin{tabular}{|c|c|c|c|}
\hline No & Statistik & $\begin{array}{c}\text { Kelas } \\
\text { Eksperimen A }\end{array}$ & $\begin{array}{c}\text { Kelas } \\
\text { Eksperimen B }\end{array}$ \\
\hline 1 & Jumlah Siswa & 30 & 30 \\
\hline 2 & Jumlah Nilai & 2440 & 2352 \\
\hline 3 & Rata-Rata & 81,3 & 78,4 \\
\hline 4 & Varians & 41,19 & 42,59 \\
\hline 5 & Maksimum & 92 & 92 \\
\hline 6 & Minimum & 68 & 68 \\
\hline
\end{tabular}

\section{Analisis Data}

\section{Uji Normalitas Data}

Salah satu persyaratan analisis yang harus dipenuhi sebelum melakukan uji statistik parametrik adalah sebaran data kedua sampel harus berdistribusi normal. Untuk mengetahui sebaran data berdistribusi normal atau tidak dapat dilakukan uji normalitas dengan menggunakan uji Chi-
Square dengan syarat normal yang harus dipenuhi adalah $\chi^{2}{ }_{\text {hitung }}<\chi_{\text {tabel }}^{2}$ pada taraf $\alpha=0,05$. Secara ringkas hasil perhitungan uji normalitas data pretest dan postest pada masing-masing kelas dapat dilihat pada Tabel 3.

Tabel 3. Ringkasan Hasil Uji Normalitas Data

\begin{tabular}{|l|l|l|l|l|l|l|}
\hline \multirow{2}{*}{ Kelas } & \multicolumn{3}{|l|}{ Pretest } & \multicolumn{1}{l|}{ Postest } \\
\cline { 2 - 7 } & $\boldsymbol{\chi}^{\mathbf{2}}{ }_{\text {hitung }}$ & $\boldsymbol{\chi}^{\mathbf{2}}{ }_{\text {tabel }}$ & Ket & $\boldsymbol{\chi}^{\mathbf{2}}{ }_{\text {hitung }}$ & $\boldsymbol{\chi}^{\mathbf{2}}{ }_{\text {tabel }}$ & Ket \\
\hline Eksperimen A & 6,292 & 9,488 & Normal & 6,345 & 9,488 & Normal \\
\hline Eksperimen B & 6,283 & 9,488 & Normal & 3,179 & 9,488 & Normal \\
\hline
\end{tabular}

\section{Uji Homogenitas Data}

Pengujian homogenitas data diuji menggunakan uji $\mathrm{F}$ yang bertujuan untuk mengetahui kehomogenan varians data-data kelompok sampel penelitian. Data masingmasing kelompok sampel dinyatakan memiliki varians yang homogen, apabila nilai $\mathrm{F}_{\text {hitung }}<\mathrm{F}_{\text {tabel }}$ pada taraf $\alpha=0,05$. Secara ringkas hasil perhitungan uji homogenitas data kedua kelas diperlihatkan pada Tabel 4 berikut.

Tabel 4 Ringkasan Hasil Uji Homogenitas

\begin{tabular}{|l|l|l|l|l|l|}
\hline Data & $\begin{array}{l}\text { Varians } \\
\text { Terbesar }\end{array}$ & $\begin{array}{l}\text { Varians } \\
\text { Terkecil }\end{array}$ & $\boldsymbol{F}_{\text {hitung }}$ & $\boldsymbol{F}_{\text {tabel }}$ & Ket \\
\hline Pretest & 30,54 & 29,95 & 1,019 & 1,85 & Homogen \\
\hline Postest & 42,59 & 41,19 & 1,033 & 1,85 & Homogen \\
\hline
\end{tabular}

Berdasarkan Tabel 4 diperoleh bahwa $F_{\text {hitung }}<F_{\text {tabel }}$ maka data pretest dan postest kelas eksperimen A dan kelas eksperimen B memiliki varians yang sama atau homogen. 


\section{Uji Hipotesis}

Setelah diketahui kedua kelompok data kemampuan pemahaman konsep matematika siswa adalah berdistribusi normal dan mempunyai varians yang homogen, selanjutnya dilakukan uji hipotesis dengan menggunakan uji t, hal ini dilakukan untuk mengetahui apakah hipotesis penelitian diterima atau ditolak.

Pengujian hipotesis yang dilakukan pada data postest, diuji statistik satu pihak dengan cara membandingkan rata-rata postest antara kelas eksperimen A dan kelas eksperimen B. Adapun hipotesis penelitian ini adalah :

$\mathrm{H}_{0} \quad$ Tidak terdapat perbedaan kemampuan pemahaman konsep siswa yang diajarkan dengan menggunakan model pembelajaran Contextual Teaching And Learning (CTL) dan siswa yang diajarkan dengan model pembelajaran Penemuan Terbimbing

$\mathrm{H}_{\mathrm{a}}$ Terdapat perbedaan kemampuan pemahaman konsep siswa yang diajarkan dengan menggunakan model pembelajaran Contextual Teaching And Learning (CTL) dan siswa yang diajarkan dengan model pembelajaran Penemuan Terbimbing

Secara ringkas hasil perhitungan uji hipotesis data kedua kelas diperlihatkan pada Tabel 5 berikut ini.

Tabel 5 Ringkasan Hasil Pengujian Hipotesis

\begin{tabular}{|l|l|l|l|l|l|}
\hline No & Kelas & Rata-Rata & $\boldsymbol{t}_{\text {hitung }}$ & $\boldsymbol{t}_{\text {tabel }}$ & Kesimpulan \\
\hline 1 & Eksperimen A & 81,33 & \multirow{2}{*}{1,80} & 1,672 & $H_{1}$ diterima \\
\hline 2 & Eksperimen B & 78,4 & & & \\
\hline
\end{tabular}

Berdasarkan tabel di atas hasil pengujian pada taraf signifikan $\alpha=0,05 \mathrm{dan} \mathrm{dk}=30$ $+30-2=58$ dengan hasil $t_{\text {hitung }}=1,80$ dan $t_{\text {tabel }}=1,672$ sehingga terlihat bahwa $t_{\text {hitung }}>$ $t_{\text {tabel }}$ yaitu 1,80 > 1,672 yang berarti bahwa $H_{0}$ ditolak dan $H_{1}$ diterima. Sehingga disimpulkan bahwa terdapat perbedaan kemampuan pemahaman konsep siswa yang diajarkan dengan menggunakan model pembelajaran Contextual Teaching And Learning (CTL) dan siswa yang diajarkan dengan model pembelajaran Penemuan Terbimbing di MTs.S Al-Jihad Medan T.A 2017/2018.

\section{Pembahasan}

Penelitian yang dilakukan di MTs.S Al-Jihad Medan ini adalah penelitian yang mengungkapkan perbedaan kemampuan pemahaman konsep matematika siswa dengan menggunakan model pembelajaran kontekstual dan Penemuan Terbimbing di kelas VII MTs.S Al-Jihad Medan. Penelitian ini melibatkan dua kelas eksperimen A dan kelas eksperimen B.
Kedua kelas diberi perlakuan yang berbeda, yaitu kelas eksperimen A diberi perlakuan dengan menggunakan model pembelajaran kontekstual (CTL) dan kelas eksperimen B diberi perlakuan dengan menggunakan model pembelajaran Penemuan Terbimbing.

Setelah diberi perlakuan yang berbeda pada kelas eksperimen A dan kelas eksperimen B, kemudian kedua kelas diberikan posttest atau tes akhir untuk mengetahui kemampuan pemahaman konsep matematikanya. Dari hasil postest yang ada diperoleh rata-rata nilai postest kemampuan pemahaman konsep matematika siswa kelas eksperimen A yaitu 81,3 lebih tinggi daripada rata-rata nilai posttest kemampuan pemahaman konsep matematika siswa kelas eksperimen B yaitu 78,4 . Hal diatas dibuktikan dengan dilakukannya pengujian hipotesis dengan menggunakan uji $t$ satu pihak. Setelah dilakukan uji hipotesis pada data postest pemahaman konsep matematika siswa, secara statistik diperoleh $t_{\text {hitung }}(1,80)>t_{\text {tabel }}$ $(1,672)$ yang berarti bahwa Ho ditolak dan

Raja Sopiyah Nasution, Syafari. Perbandingan Pemahaman Konsep Siswa dengan Menggunakan Model Pembelajaran Contextual Teaching and Learning dan Penemuan Terbimbing di Kelas VIIMts.S Al-Jihad Medan. Jurnal Inspiratif, Vol. 4, No. 1 April 2018. 
$\mathrm{H}_{\mathrm{a}}$ diterima. Sehingga disimpulkan bahwa terdapat perbedaan kemampuan pemahaman konsep siswa yang diajarkan dengan menggunakan model pembelajaran Contextual Teaching And Learning (CTL) dan siswa yang diajarkan dengan model pembelajaran Penemuan Terbimbing.

Hal ini sejalan dengan penelitian yang dilakukan oleh Zahrah, Surya dan Syahputra (2017) yang berjudul The Application Of Ctl To Improve Students' Understanding Concept Ability By Matflash Graphic Media Assistance dengan kesimpulan "implementating contextual learning with graphic media can improve students' mathematic concept understanding in addition and subtraction of integer in VIII Grade of Junior High School Garut Regency" (Implementasi pembelajaran kontekstual dengan media grafis dapat meningkatkan pemahaman konsep matematika siswa di penambahan dan pengurangan bilangan bulat di kelas VIII Kabupaten Garut).

Pembelajaran kontekstual (CTL) memberi kesempatan bagi siswa untuk mendorong dan menggunakan pemahamannya dalam menyelesaikan berbagai persoalan yang dihadapinya pada kehidupan sehari-hari mereka. Pada pelaksanaan pembelajaran kontekstual yaitu pada kelas eksperimen A, peneliti dalam hal ini bertindak sebagai guru tidak banyak menemui kesulitan dalam mengajar. Siswa cukup koperatif dan antusias dalam melaksanakan kegiatan pembelajaran. Pada awal kegiatan pembelajaran, setelah memberikan apersepsi, guru membagikan LAS yang berisi permasalahan kontekstual yang terkait dengan kehidupan sehari-hari siswa. Dengan adanya permasalahan kontekstual tersebut membuat siswa tertarik dan termotivasi untuk menyelesaikannya. Selain itu, kesan matematika yang abstrak dan sukar sudah dapat dikurangi sehingga memudahkan mereka untuk memahami bahwa konsep bilangan pecahan. Hal ini sejalan dengan Trianto (2011:108) yang mengemukakan bahwa "penerapan pembelajaran kontekstual akan sangat membantu guru untuk menghubungkan materi pelajaran dengan situasi dunia nyata dan memotivasi siswa membuat hubungan antara pengetahuan dan penerapannya dalam kehidupan mereka sebagai anggota keluarga, warga negara dan pekerja".

Hal senada juga dikemukakan oleh Rusman (2011:189) yaitu "CTL adalah pembelajaran yang memungkinkan terjadinya proses belajar dimana siswa menggunakan pemahaman dan kemampuan akademiknya untuk memecahkan masalah yang bersifat simulatif ataupun nyata, baik sendiri-sendiri maupun bersama-sama". Harahap dan Surya (2017) menyatakan bahwa penyelesaian masalah matematika merupakan proses mental tingkat tinggi dan memerlukan proses berpikir yang lebih kompleks.

Beranjak dari permasalahan kontekstual siswa diajak untuk menemukan kembali rumus atau konsep yang dapat digunakan untuk memecahkan permasalahan kontekstual tersebut. Pada saat menemukan sebuah konsep siswa selalu dikondisikan kedalam kelompokkelompok belajar. Dalam kelompok belajar siswa selalu didorong untuk mengkontruksi pengetahuan yang dimilikinya. Adanya kelompok belajar memudahkan siswa untuk sharing, saling bertanya dan bekerja sama dengan teman lainnya. Siswa yang terlibat dalam kelompok belajar saling memberikan informasi yang diperlukan oleh teman bicaranya. Hal ini sejalan dengan Widyaningrum, dkk. (2013) yang mengatakan bahwa "Pembelajaran matematika dengan berkelompok membuat siswa dapat berkomunikasi secara aktif, baik dengan guru maupun dengan siswa yang lain dalam proses pembelajaran". Pada saat siswa bekerja, peneliti dalam hal ini sebagai guru memberikan bimbingan dan arahan kepada siswa baik secara individu maupun secara berkelompok. Di akhir kegiatan pembelajaran, guru meminta siswa untuk melakuan refleksi pembelajaran dan memberikan penghargaan kepada kelompok belajar yang telah melakukan presentasi.

$$
\text { Meningkatnya kemampuan }
$$

pemahaman konsep matematika siswa 
dengan penerapan model pembelajaran kontekstual ini disebabkan adanya penerapan ketujuh prinsip pembelajaran kontekstual yaitu konstruktivisme, menemukan (inquiry), bertanya (questioning), masyarakat belajar (learning community), pemodelan (modeling), refleksi (reflection), dan penilaian yang sebenarnya. Hal ini sejalan dengan hasil penelitian yang dilakukan oleh Fuadi (2016) yang mengatakan bahwa "pendekatan pembelajaran kontekstual dengan tujuh komponennya memberi kontribusi besar terhadap peningkatan kemampuan pemahaman dan penalaran siswa dalam pembelajaran matematika".

Hal diatas juga senada dengan penelitian yang dilakukan Suhartini, Syahputra, dan Surya (2016) yang berjudul "Pengaruh Pembelajaran Kontekstual Terhadap Kemampuan Pemecahan Masalah Matematik Dan Kemandirian Belajar Siswa di Mts Miftahussalam Medan" menemukan bahwa pembelajaran kontekstual berpengaruh lebih signifikan dibandingkan pengaruh pembelajaran konvensional terhadap kemampuan pemecahan masalah matematik dan kemandirian siswa.

Juga senada dengan penelitian yang dilakukan oleh Rusmini dan Surya (2017) yang berjudul The Effect of Contextual Learning Approach to Mathematical Connection Ability and Student Self Confidence Grade VIII SMP Negeri 8 Medan menemukan "learning mathematics using contextual learning model to students of SMK Harapan Mekar-2 Medan was effective if it was considered from students' learning mastery, Students' learning activities, and teachers' ability to manage learning and students' responses" (Pembelajaran matematika menggunakan model pembelajaran kontekstual kepada siswa SMK Harapan Mekar-2 Medan efektif jika dilihat dari penguasaan belajar siswa, kegiatan belajar siswa, dan kemampuan guru untuk mengelola pembelajaran dan tanggapan siswa).

Pelaksanaan pembelajaran Penemuan Terbimbing di kelas eksperimen $\mathrm{B}$ diawali dengan membuat seluruh isi kelas berbicara tentang materi yang dipelajari serta manfaat mempelajarinya dengan cara melakukan tanya jawab. Kemudian peneliti dalam hal ini sebagai guru membagi siswa ke dalam beberapa kelompok belajar yang nantinya melalui kelompok belajar ini siswa akan mengerjakan soal-soal yang berisi permasalahan-permasalahan seputar materi bilangan pecahan. Pada tahap akhir pembelajaran, guru meminta siswa untuk melakukan refleksi.

Pelaksanaan pembelajaran Penemuan Terbimbing dikelas eksperimen B pada awalnya sedikit mengalami hambatan. Kinerja peneliti dalam hal ini sebagai guru dalam pengelolaan pembelajaran belum dilaksanakan dengan baik dan motivasi yang diberikan guru masih terlalu sedikit karena model pembelajaran ini tergolong sebagai model pembelajaran yang baru bagi guru dan juga siswa. Kegaduhan yang terjadi pada waktu pembentukan kelompok sedikit menyita waktu pembelajaran. Kerja sama siswa dalam kelompok juga belum dilaksanakan dengan baik, masih banyak siswa yang pasif dalam kelompoknya. Sementara menurut Murizal (2012) memberikan kesimpulan bahwa "apabila cara guru menyampaikan materi pelajaran disenangi siswa, maka setiap siswa akan bersungguhsungguh dalam mempelajarinya". Penelitian yang berjudul "Pengembangan Perangkat Pembelajaran Berbantuan Autograph Untuk Meningkatkan Pemahaman Konsep Matematik Siswa SMK Melalui Model Penemuan Terbimbing" yang dilakukan oleh Wasriono, Syahputra, dan Surya (2015) menyimpulkan bahwa pemahaman konsep matematika siswa menggunakan perangkat pembelajaran yang di kembangkan dengan model pembelajaran penemuan terbimbing mengalami peningkatan dari ujicoba I ke ujicoba II. Sehingga kinerja peneliti sebagai guru dalam menerapkan pembelajaran Penemuan Terbimbing di kelas eksperimen B yang belum dilaksanakan dengan baik menjadi kelemahan dalam penelitian ini.

Model pembelajaran kontekstual (CTL) maupun Penemuan Terbimbing sama-sama dapat menjadikan siswa terbiasa

Raja Sopiyah Nasution, Syafari. Perbandingan Pemahaman Konsep Siswa dengan Menggunakan Model Pembelajaran Contextual Teaching and Learning dan Penemuan Terbimbing di Kelas VIIMts.S Al-Jihad Medan. Jurnal Inspiratif, Vol. 4, No. 1 April 2018. 
aktif dalam menyelesaikan masalah untuk mendapatkan konsep. Hal ini terjadi karena proses pembelajaran bukan hanya sekedar mentransfer ilmu dari guru kepada siswa, melainkan suatu proses yang dikondisikan atau diupayakan oleh guru, sehingga siswa aktif dengan berbagai cara membangun sendiri pengetahuannya. Dalam pembelajaran dengan model pembelajaran kontekstual (CTL) dan Penemuan Terbimbing sama-sama dapat meningkatkan kemampuan pemahaman konsep matematika di kedua kelas eksperimen tersebut. Hanya saja rata-rata hasil posttest di kelas eksperimen A dengan model pembelajaran kontekstual (CTL) lebih tinggi dibandingkan di kelas eksperimen B dengan model pembelajaran Penemuan Terbimbing dengan rincian ratarata posttest kelas eksperimen A yaitu 81,3 dan rata-rata posttest kelas eksperimen $\mathrm{B}$ yaitu 78,4 .

Hasil penelitian ini sejalan dengan beberapa hasil penelitian terdahulu yaitu peneliti yang dilakukan oleh Widyaningrum, dkk. (2013) yang menyimpulkan bahwa dengan pendekatan kontekstual berpengaruh terhadap kemampuan pemahaman konsep matematika siswa.

Penelitian yang dilakukan oleh Surya, Putri dan Mukhtar (2017) menyatakan "Improvement of mathematical problem-solving ability of students taught by contextual learning model is higher than students taught by expository learning model", (Peningkatan kemampuan pemecahan masalah siswa yang diajar dengan model pembelajaran kontekstual lebih tinggi dibandingkan dengan siswa yang diajar dengan model pembelajaran ekspositori) juga merupakan penelitian yang sejalan dengan kesimpulan dalam penelitian ini. Penelitian sejalan lainnya yaitu penelitian yang dilakukan oleh Ekowati, Darwis, Upa, dan Tahmir (2015) menyatakan juga "The applicationof a contextual approach to estblish cooperation between the students and teacher in a harmonious relationship can stimulate students to think creatively in expressing the opinions, improving communication skills, responsibility, self-confidence and also building student's interest", (Penerapan pendekatan kontekstual untuk membentuk kerjasama antara siswa dan guru dalam hubungan yang harmonis dapat menstimulasi siswa untuk berfikir kreatif dalam menyampaikan pendapat, meningkatkan kemampuan komunikasi, kemampuan merespon, percaya diri dan membangun daya tarik siswa). Penelitian yang dilakukan Nartari, Hidayat, dan Sumiyat (2015) dengan kesimpulan "Contextual learning can significantly improve mathematical ommunication skills for students", (Pembelajaran kontekstual dapat secara signifikan meningkatkan kemampuan komunikasi matematika siswa) juga mendukung kesimpulan penelitian ini. Penelitian lainnya yang mendukung penelitian ini yaitu penelitian yang dilakukan oleh Pinwanna (2015) yang menunjukkan bahwa "CTLM (Contextual Teaching And Learning Metohd) can helped students learn more efficiently", (Metode pembelajaran kontekstual dapat membantu siswa belajar lebih efisien).

Pembelajaran Contextual Teaching Learning ini sangat baik untuk diterapkan. Hal ini sesuai dengan pendapat Surya (2012) yang menyatakan guru dapat terus merancang/merencanakan, memantau, mengevaluasi, dan merefleksi serta terus memperbaiki kekurangan, kesulitan dan dapat mengatasi permasalahan yang muncul sehingga siswa memahami konsep matematika secara luwes, akurat, efesiarn, dan tepat serta memiliki sikap menghargai kegunaan matematika dalam kehidupan yaitu memiliki rasa ingin tahu atau kritis, perhatian dan minat dalam mempelajari matematika, serta sikap ulet dan percaya sendiri dalam pemecahan masalah matematika.

\section{Kesimpulan}

Dari hasil analisis yang dilakukan dalam penelitian ini diperoleh kesimpulan bahwa hasil uji hipotesis memberikan nilai $t_{\text {hitung }}=1,80$ dan $t_{\text {tabel }}=1,672$ dengan $\mathrm{dk}=$

Raja Sopiyah Nasution, Syafari. Perbandingan Pemahaman Konsep Siswa dengan Menggunakan Model Pembelajaran Contextual Teaching and Learning dan Penemuan Terbimbing di Kelas VIIMts.S Al-Jihad Medan. Jurnal Inspiratif, Vol. 4, No. 1 April 2018. 
58 dan taraf signifikan $\alpha=0,05$ sehingga terlihat bahwa $t_{\text {hitung }}(1,80)>$ $t_{\text {tabel }}(1,672)$ yang berarti bahwa bahwa $\mathrm{H}_{\mathrm{o}}$ ditolak dan $\mathrm{H}_{\mathrm{a}}$ diterima. Sehingga disimpulkan bahwa terdapat perbedaan kemampuan pemahaman konsep siswa yang diajarkan dengan menggunakan model pembelajaran Contextual Teaching And Learning (CTL) dan siswa yang diajarkan dengan model pembelajaran Penemuan Terbimbing. Begitu pula dengan rata-rata nilai postest kemampuan pemahaman konsep matematika siswa yaitu sebesar 81,33 pada kelas eksperimen A dan 78,4 pada kelas eksperimen B.

\section{DAFTAR PUSTAKA}

Abdurrahman, M. 2012. Anak Berkesulitan Belajar. Jakarta: Rineka Cipta

Ekowati, K.., Muhammad Darwis., Pua Upa., Suradi Tahmir., (2015), The Application of Contextual Approach in Learning Mathematics to Improve Student Motivation at SMP Negeri 1 Kupang, International Education Studies, 8 (8) : 81-86.

Harahap, E. R., dan Surya, E. (2017). Kemampuan Pemecahan Masalah Matematis Siswa Kelas VII dalam Menyelesaikan Persamaan Linear Satu Variabel. Edumatica, Volume 07 Nomor 01 April 2017, 44-54.

Hendriana, Heris., Slamet, Ujung Rahmat., Sumarmo, Utari., (2014), Mathematical Connection Ability And Self-Confidence (An Experiment On Junior High School Students Through Contextual Teaching And Learning With Mathematical Manipulative), International Journal of Education, $8(1): 1-11$.

Murizal, A, 2012, Pemahaman Konsep Matematis dan Model Pembelajaran Quantum Teaching, Jurnal
Pendidikan Matematika, Vol. 1 No. 1: 123.

Pinwanna, M., (2015), Using the Contextual Teaching and Learning Method in Mathematics to Enhance Learning Efficiency on Basic Statistics for High School Students, The International Conference on Language, Education, Humanities and Innovation, 1 (8) : 58-63

Rusman, dkk (2011) Pembelajaran Berbasis Teknologi Informasi dan Komunikasi : Mengembangkan Profesionalisme Guru. Jakarta:Rajawali Pers. PT. Raja Grafindo Persada.

Rusmini, Surya, E., (2017), The Effect of Contextual Learning Approach to Mathematical Connection Ability and Student Self Confidence Grade VIII SMP Negeri 8 Medan International Journal of Sciences, Basic and Applied Research (IJSBAR), 35 (2) : 249-262

Sudjana, N. 2006. Penilaian Hasil Proses Belajar Mengajar. Bandung: PT Remaja Rosdakarya.

Suhartini, I., Syahputra, E., Surya, E., (2016), Pengaruh Pembelajaran Kontekstual Terhadap Kemampuan Pemecahan Masalah Matematik Dan Kemandirian Belajar Siswa Di Mts Miftahussalam Medan, PARADIKMA, 9 (3) : 62-71

Surya, E.., Putri, Feria Andriana., Mukhtar, (2017), Improving Mathematical Problem Solving Ability and Self Confidence of High School Students Through Contextual Learning Model, Journal of Mathematics Education, 8 (1) : 8594

Surya, E. (2012). "Upaya Pembelajaran Matematika Berbasis Masalah dengan Strategi Konflik Kognitif". Jurnal Tematik, PPS Dikdas Unimed. 7, (1), 1-14, ISSN : 19790633.

Tambelu, Jackson V.A, (2013), Development of Mathematical

Raja Sopiyah Nasution, Syafari. Perbandingan Pemahaman Konsep Siswa dengan Menggunakan Model Pembelajaran Contextual Teaching and Learning dan Penemuan Terbimbing di Kelas VIIMts.S Al-Jihad Medan. Jurnal Inspiratif, Vol. 4, No. 1 April 2018. 
Learning Based Contextual Model in South Minahasa Regency, Journal of Education and Practice, 4 (15) : 27-32

Trianto. 2010. Mendesain Model Pembelajaran Inovatif Progresif: Konsep, Landasan, Implementasinya pada Kurikulum Tingkat satuan Pendidikan (KTSP). Jakarta: Prenada Media

Wardhani, Sri. 2008. Analisis SI dan SKL Mata Pelajaran Matematika SMP/MTs untuk Optimalisasi Tujuan Mata Pelajaran Matematika. Yogyakarta: Pusat Pengembangan dan Pemberdayaan Pendidik dan Tenaga Kependidikan Matematika.

Wasriono, Syahputra, E., Surya, E, (2015), Pengembangan Pembelajaran Perangkat Autograph Untuk Meningkatkan
Pemahaman Konsep Matematik Siswa SMK Melalui Model Penemuan Terbimbing, Jurnal Paradikma, 8 (3) : 52-61.

Widyaningrum, A.Z., Suyadi, G. dan Nurhanurawati. 2013. Pengaruh Penerapan Pendekatan Kontekstual terhadap Pemahaman Konsep Matematis Siswa: Jurnal Pendidikan Matematika Vol. 1 No. 1, FKIP Universitas Lampung.

Wilis, Ratna. 2012. Teori-Teori Belajar Dan Pembelajaran. Jakarta : Penerbit Erlangga

Zahrah, Afifah., Surya, E., Syahputra, E., (2017), The Application Of Ctl To Improve Students' Understanding Concept Ability By Matflash Graphic Media Assistance IJARIIE-ISSN (O)-2395-4396, 3 (1) : 3222-3230 